\title{
Benchmarking of Wellhead Safety Zone Criteria for Underground Gas Storage Facilities
}

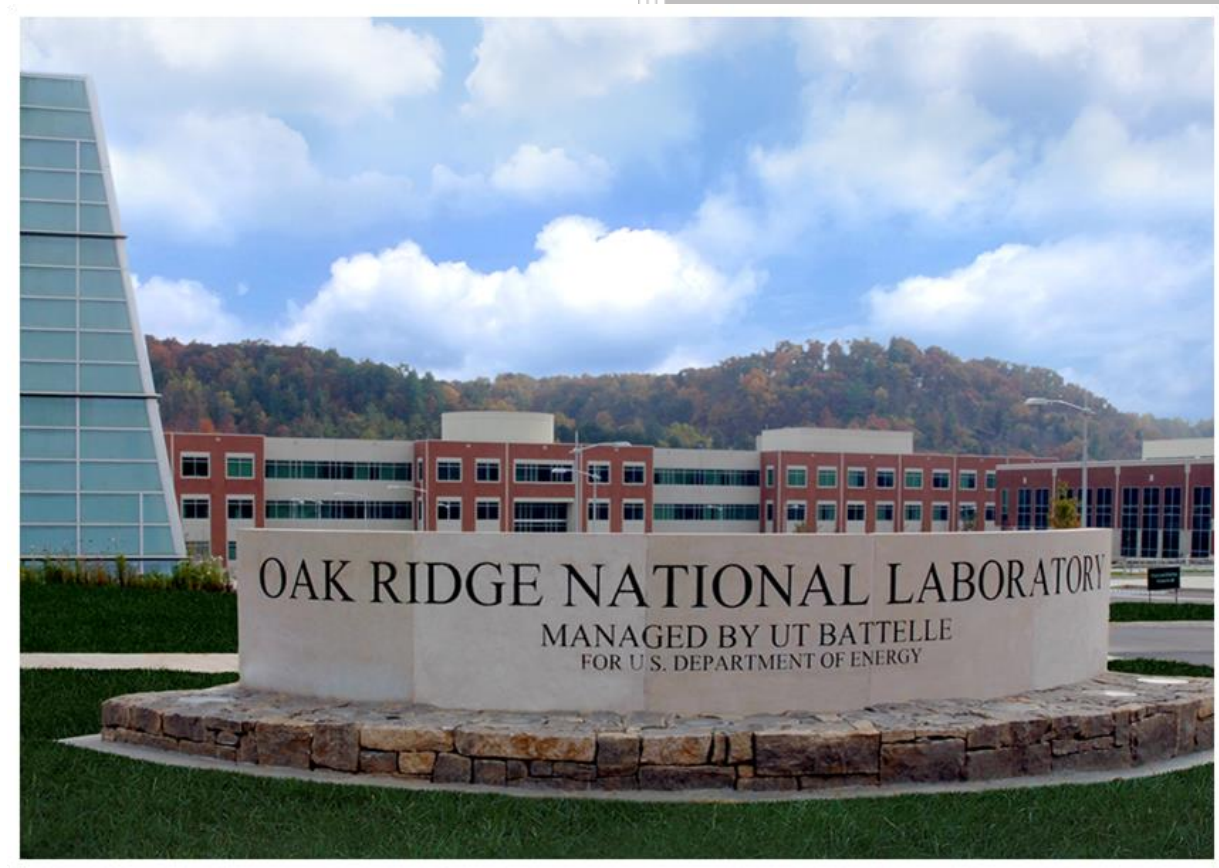

\section{Approved for public release. Distribution is unlimited.}

C. David Sulfredge

Simon D. Rose

August 2019 


\title{
DOCUMENT AVAILABILITY
}

Reports produced after January 1, 1996, are generally available free via US Department of Energy (DOE) SciTech Connect.

Website www.osti.gov

Reports produced before January 1, 1996, may be purchased by members of the public from the following source:

\author{
National Technical Information Service \\ 5285 Port Royal Road \\ Springfield, VA 22161 \\ Telephone 703-605-6000 (1-800-553-6847) \\ TDD 703-487-4639 \\ Fax 703-605-6900 \\ E-mail info@ntis.gov \\ Website http://classic.ntis.gov/
}

Reports are available to DOE employees, DOE contractors, Energy Technology Data Exchange representatives, and International Nuclear Information System representatives from the following source:

Office of Scientific and Technical Information

PO Box 62

Oak Ridge, TN 37831

Telephone 865-576-8401

Fax 865-576-5728

E-mail reports@osti.gov

Website http://www.osti.gov/contact.html

This report was prepared as an account of work sponsored by an agency of the United States Government. Neither the United States Government nor any agency thereof, nor any of their employees, makes any warranty, express or implied, or assumes any legal liability or responsibility for the accuracy, completeness, or usefulness of any information, apparatus, product, or process disclosed, or represents that its use would not infringe privately owned rights. Reference herein to any specific commercial product, process, or service by trade name, trademark, manufacturer, or otherwise, does not necessarily constitute or imply its endorsement, recommendation, or favoring by the United States Government or any agency thereof. The views and opinions of authors expressed herein do not necessarily state or reflect those of the United States Government or any agency thereof. 
Computational Sciences and Engineering Division

Energy and Transportation Science Division

\title{
Benchmarking of Wellhead Safety Zone Criteria for Underground Gas Storage Facilities
}

\author{
C. David Sulfredge \\ Simon D. Rose
}

Date Published: August 2019

\author{
Prepared by \\ OAK RIDGE NATIONAL LABORATORY \\ Oak Ridge, TN 37831-6283 \\ managed by \\ UT-BATTELLE, LLC \\ for the \\ US DEPARTMENT OF ENERGY \\ under contract DE-AC05-00OR22725
}




\section{CONTENTS}

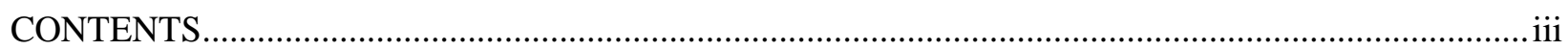

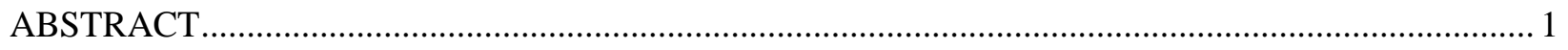

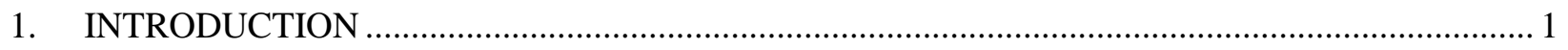

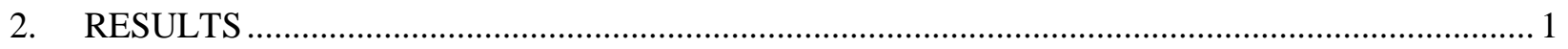

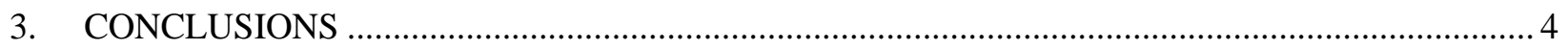

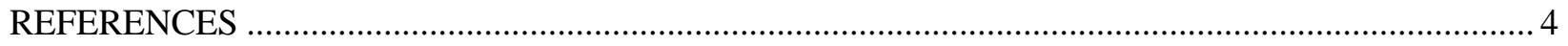




\begin{abstract}
Underground natural gas storage facilities are a vital part of the U. S. national infrastructure. However, the concept of hazard zones from fires and explosions at these facilities is not nearly as well defined as it is for natural gas transmission pipelines. This report will take a safety area predicted for underground gas storage facilities called the Wellhead Safety Zone or WSZ and benchmark it against the observed damage zone from the drill rig accident near Rama, Louisiana on November 15, 2007. When combined with earlier accidents, this new benchmark indicates the WSZ formula gives an accurate indication of the hazard radius from underground gas storage facility accidents over a wide range of casing sizes and pressures.
\end{abstract}

\title{
1. INTRODUCTION
}

In an earlier report [1], Oak Ridge National Laboratory (ORNL) adapted the widely accepted criterion of Stephens [2] for the potential hazard zone from a natural gas pipeline break to the somewhat different situation of gas discharge from an underground storage reservoir. The hazard zone is expressed as the radius for which average radiant heat flux from a natural gas fire would be greater than or equal to 5000 $\mathrm{Btu} / \mathrm{hr}^{-\mathrm{ft}^{2}}$. Gas ignition was assumed to take place immediately after the pipe rupture. The resulting formula obtained by ORNL for the Wellhead Safety Zone (WSZ) radius is:

$$
\mathrm{WSZ}=1.008^{*}\left(\mathrm{P}^{*} \mathrm{~d}^{2}\right)^{1 / 2}
$$

where $\mathrm{P}$ is the absolute pipeline pressure in psia, $\mathrm{d}$ is the line diameter in inches, and the WSZ is expressed in feet [1].

The primary incident used to calibrate the new WSZ safety criterion for underground gas storage facilities was the Moss Bluff, TX accident of August 2004. Moss Bluff involved the blowdown of a natural gas reservoir with an initial pressure of 1898 psi and a wellhead diameter of 20 inches. The observed burn damage radius at Moss Bluff was $840 \mathrm{ft}$ from the wellhead. This radius was used to establish a combustion efficiency factor of $\eta=0.50$ for the escaping gas and size the coefficient of 1.008 in Eq. (1) for the WSZ. Equation (1) then yields a WSZ for Moss Bluff of $878 \mathrm{ft}$, which is a very good correspondence with the observed burn radius of $840 \mathrm{ft}$ at Moss Bluff [1].

\section{RESULTS}

Additional data has now become available for benchmarking the WSZ criterion against a drill rig blowout that occurred near Rama, Louisiana on November 15, 2007. Figure 1 shows a picture of the resulting natural gas fire following the blowout [3]. As seen in the picture, the drill rig was located $270 \mathrm{ft}$ from the westbound lanes of Interstate I-10. The macadam road topping and concrete structural supports of I-10 were not damaged by the fire as shown in Figure 2, although a number of trees between the road and the fire were incinerated. 


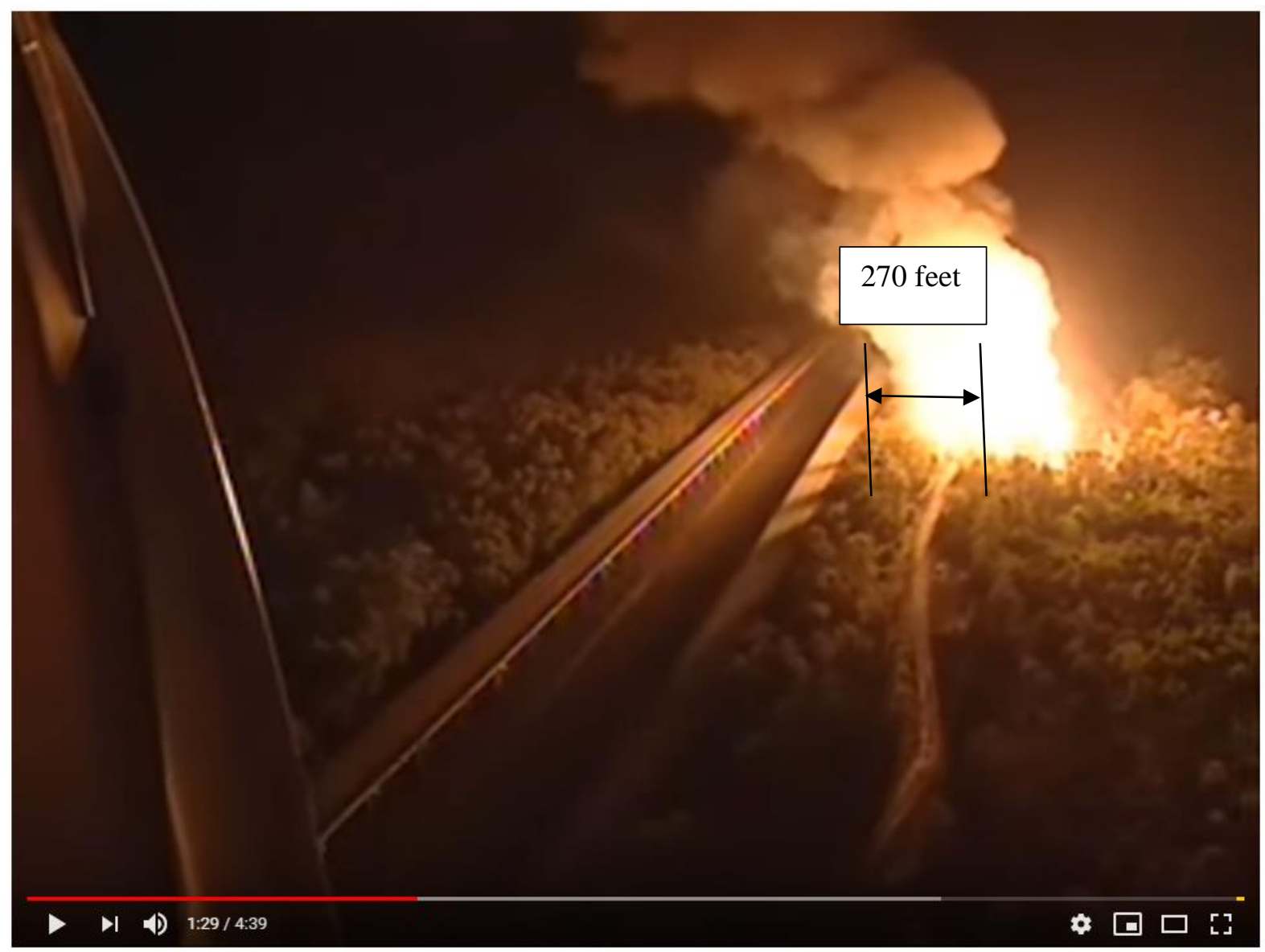

Rig Blowout Rama Louisiana-November 15th, 2007

Figure 1. Photograph of the natural gas fire and proximity to I-10 for the Rama Louisiana rig blowout [3]. 


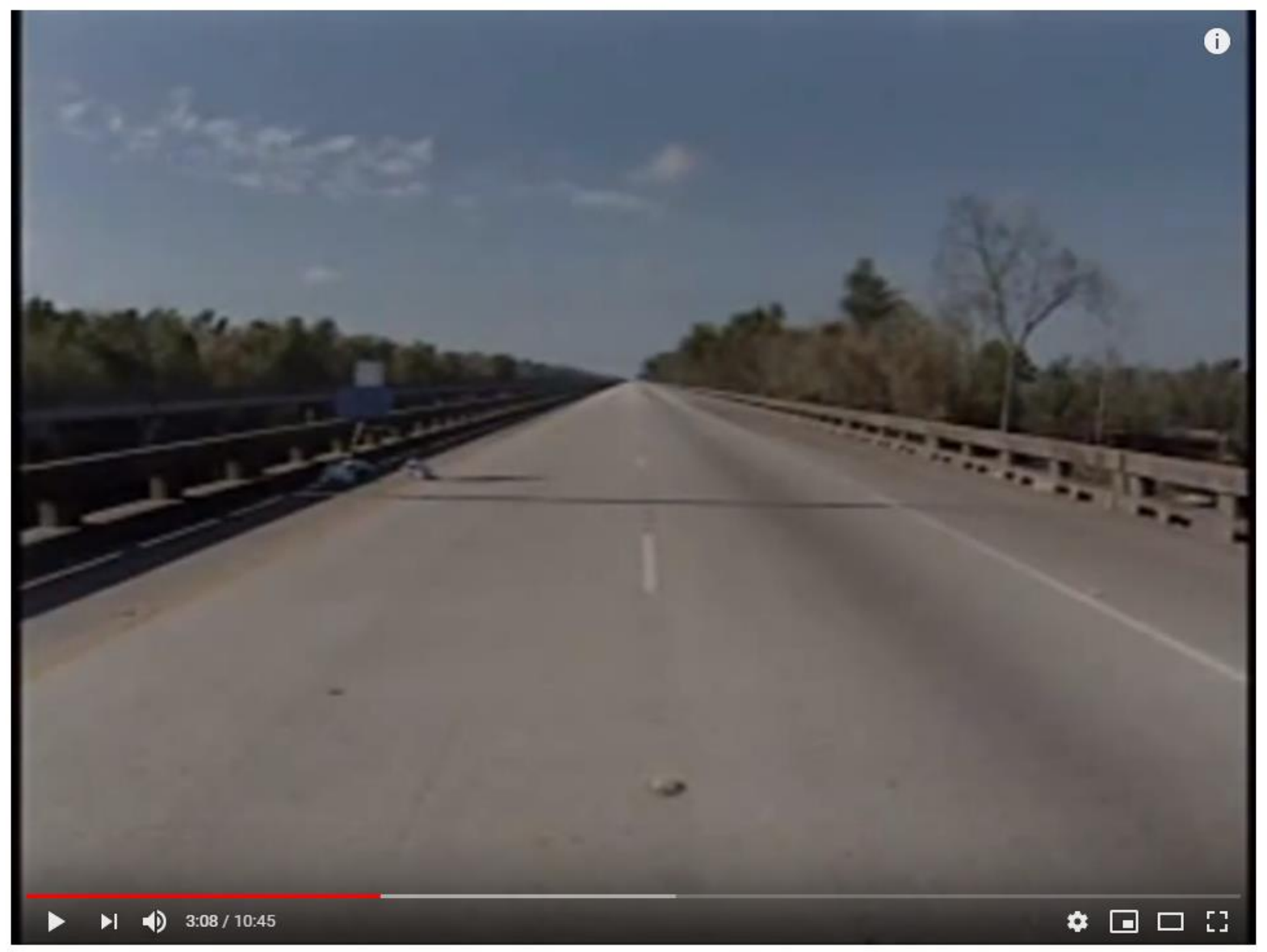

1-10 blow out

Figure 2. Macadam road surface of I-10, showing the lack of fire damage from the Rama Louisiana accident of November 15, 2007 [3]. 
Wellhead pressure from the Louisiana accident was $3600 \mathrm{psi}$, and drilling operations were in progress at the time of the blowout and fire. The drill pipe which was the source of the escaping gas had an outer diameter of 5 inches and an inner opening diameter of 4.2 inches that defined the flow area. Substituting these values into the WSZ formula yields:

$$
\mathrm{WSZ}=1.008 *\left[3600 *(4.2)^{2}\right]^{1 / 2}=254 \mathrm{ft},
$$

for the Rama, Louisiana accident. This result compares very well with the observation that damage did not extend all the way to I-10, which was $270 \mathrm{ft}$ from the gas well.

\section{CONCLUSIONS}

It should be noted that this comparison with the Louisiana accident helps validate the WSZ formula for a significantly different set of wellhead conditions than were present at Moss Bluff (3600 psi vs. 1898 psi pressure and 4.2 inch pipe vs. 20 inch pipe). Hence it would appear that the WSZ formula gives an accurate indication of the hazard radius from underground gas storage facility accidents over a wide range of casing sizes and pressures.

\section{REFERENCES}

1. C. David Sulfredge and Simon D. Rose, Development of Wellhead Safety Zone Criteria for Underground Gas Storage Facilities, ORNL/TM-2018/945, Oak Ridge National Laboratory, Oak Ridge, TN, August 2018.

2. M. J. Stephens, A Model for Sizing High Consequence Areas Associated with Natural Gas Pipelines, Topical Report prepared for the Gas Research Institute by C-FER Technologies, GRI-00/0189, October 2000.

3. https://www.youtube.com/watch?v=Q0F-y9ZwK3w 
ORNL/TM-2019/1275

\section{INTERNAL DISTRIBUTION}

1. S. D. Rose

2. C. D. Sulfredge

\section{EXTERNAL DISTRIBUTION}

3. A. P. Franks, AFEnergy, LLC, 11757 W. Ken Caryl Ave., \#F273, Littleton, CO 80127

4. J. Pfeifle, Pipeline and Hazardous Material Safety Administration, 820 Bear Tavern Rd., Suite 103, West Trenton, NJ 08628 